Mr. Byng not only traced the growth of the need for training in administration selected $m \in$ mbers of staffs and the encouragement given towards that end by professional institutions : he also pointed out quite clearly that in the staff college he visualized, the curriculum would be concerned with broad administrative problems, and would exclude subjects covered by ordinary training.

\section{A National Administrative Staff College}

Mr. Byng made it clear, too, that the outstanding feature of the scheme of a national administrative staff college was that it would be highly selective. No matter in what department-accounting, commercial, engineering and the like-candidates for admission had served, only those who had shown themselves likely to qualify for higher grades of administrative responsibility would be considered. Moreover, while the course would extend over five months, not more than one quarter of the time would be devoted to formal instruction. The remainder would be occupied by discussions, practical exercises directed to testing powers of exposition, of investigating problems, drawing up reports and so on. Already, Mr. Byng told his audience, the group responsible for this proposal claim that among some two hundred and fifty people who have been consulted (and they include members of the Government, both Houses of Parliament, representatives of the Civil Service, local government, industry and the universities) all but a few have expressed their approval. We are glad to note these opinions from varied sides of our national life because they reinforce another of the points made by Mr. Byng. It is that industrialists and business men are ready, if not anxious, for an all-inclusive staff college. They would welcome the idea that picked men from the Civil Service should study together with picked men from their own ranks. We believe there is much to commend the idea. The growth of large-scale organizations, and of quasi-public corporations controlling services pre. viously rendered by private enterprise, have made the differences between business and the public services much less definite than they used to be. Indeed, the relations between the business world and the Government departments become more and more intimate and complex. The War has added strength to that tendency and there would be obvious advantages in bringing together what Mr. Byng calls "the future administrators of both worlds", during a critical part of their training.

\section{Post-War Demobilization of Scientific and other Personnel}

A DEFINITE step in preparation for the demobilization of scientific, technical and professional staff from the Services and from the war industries at the end of hostilities and for their redistribution in suitable occupations both at home and overseas has now been taken by the Minister of Labour and National Service in the appointment of a Committee of Inquiry, with Lord Hankey as chairman. The Committee includes Mr. J. S. Duncan, Deputy High Commissioner for Australia, and the Dominions of Canada, New Zealand and South Africa will be represented by observers. The terms of reference are : To consider and report upon the arrangements which should be made to facilitate the employment after the end of hostilities of men and women qualified. to undertake responsible work in the professions or elsewhere, with particular reference to $(a)$ the organization, premises and staff of the Appointments Department of the Ministry of Labour and National Service; and $(b)$ the arrangements which should be made for co-operation between the Appointments Department and other organizations and institutions (including professional, industrial and commercial organizations) and universities, at home and abroad. In addition to those named above, the Committee includes Mr. H. M. Barton, Sir Bernard Bowdillon, Mr. J. T. Davis, Mr. R. H. Dobson, Sir William Fyfe, Mrs. Mary Hamilton, Mr. Clement Jones, Dr. H. Lowery, Mr. John McLean, Mr. Godfrey Mitchell, the Hon. Eleanor Plumer, Prof. R. V. Southwell, Mr. H. V. Tewson, Mr. Henry Thirkill, and Mr. G. W. Thomson, with Mr. H. F. Rossetti and Mr. F. M. H. Markham, Ministry of Labour and National Service, as secretaries.

\section{Coal Carbonization and the Economy of Britain}

THE Institute of Gas Engineers held its eightieth annual general meeting in London on June 9, and the president, Mr. E. V. Evans, surveyed the industry of coal carbonization and its place in the war and postwar economy of Great Britain. To the general public, coal is just something to burn, but in the last genera. tion we have seen the oil industry convert a raw material into a great variety not only of fuels but also of chemical products. To-day it is generally agreed that the coal industry must do likewise. The gas industry, of all fuel industries, so far has de. veloped the processing of coal to the greatest extent. Mr. Evans' address revealed the far-reaching ramifications of the industry in the national fuel economy. But the section which seems to merit most careful scrutiny is the discussion of what may be anticipated from a co-operative scheme in which the public utilities co-operate instead of competing in the supply of electricity and gas, each supplying the public with its product in directions for which it is most fitted. The argument assumes the existence of a town of 200,000 inhabitants with the services normally developed and with prices as at present. It assumes that in three stages conditions alter in a normal manner leading to a result which may be summarized as follows : Consumption of gas would increase fourfold, while average price per therm would fall from $10 \cdot 4 d$. to $6 \cdot 22 d$. Consumption of electricity would double and average price fall from $0 \cdot 98 d$. to $0 \cdot 7 d$. per unit. Fuel bill for the average domestic consumer would fall from $£ 17.9$ to $£ 16$. Transport of solid fuel and ash through streets would fall to less than one fifth. The total amount of coal consumed for fuel and power would be reduced from 580,000 tons to 517,000 tons. Atmospheric pollution would be practically abolished, and recovery of byproducts-tar, benzole, sulphur and ammoniaincreased about fourfold. These gains require only the application of existing and technical knowledge, directed according to a national plan for the efficient use of coal.

\section{Association of Special Libraries and Information Bureaux}

The report of the proceedings of the seventeenth conference of the Association of Special Libraries and Information Bureaux held in London during November $7-8,1942$, has now been issued. It con- 